\title{
More than skin deep
}

\author{
From patriotism to martyrdom to surgery, Andrew Krasnow's American flag made from \\ human skin reveals many layers of what it is to be human, finds Martin Kemp.
}

Flags are not benign human inventions. At their best they identify communities that give support for meaningful human lives. But at their frequent worst they are waved aggressively in the faces of outsiders. The schematic heraldry of flags is both primitive and enduringly potent.

At one level, flags are robustly unambiguous, but in the emotional domain they are open to polarized readings. For patriotic Americans who attended the inauguration of President Barack Obama, the Stars and Stripes connotes what is good about living in one of the 50 states. For those who collectively or individually see the United States in an opposed light, the flag looks 'ugly'.

When an artist takes on the Stars and Stripes, as Jasper Johns did with his famous series of thickly painted flags from 1954 onwards, openness of reading takes over. Was Johns being patriotic or anti-patriotic? Was he treating the flag as a 'pop' object like Andy Warhol's Brillo Boxes? The paintings themselves do not make definite statements. a reading might raise productive ironies.

Because he is using human skin, Krasnow must adhere to legal requirements, but he insists that his supplies were legally obtained 20 years ago. By mounting an exhibition containing "relevant material" that "consists of or includes human cells", GV Art of London, the current home of the flesh flag, has to comply with the requirements of the UK Human Tissue Authority. Set up under the Human Tissue Act 2004, the authority regulates the removal, storage, use and disposal of human bodies, organs and tissues from the living and deceased. In the United States, Krasnow is also potentially violating

of Brown University in Providence, Rhode Island, the 1568 edition of Andreas Vesalius's anatomical masterpiece, De Humani Corporis Fabrica, is bound in human skin.

Krasnow is working in a medium that is as multivalent in potential meanings and emotional reactions as any art medium could be, even before any content enters. Flaying is full of traditional resonances. In ancient mythology, Marsyas was notoriously skinned for the temerity of his musical challenge to Apollo. St Bartholomew was excruciatingly martyred by flaying. In Michelangelo's The Last Judgment in the Sistine Chapel in Vatican City, Italy, the knife-wielding saint, fully intact in heaven,

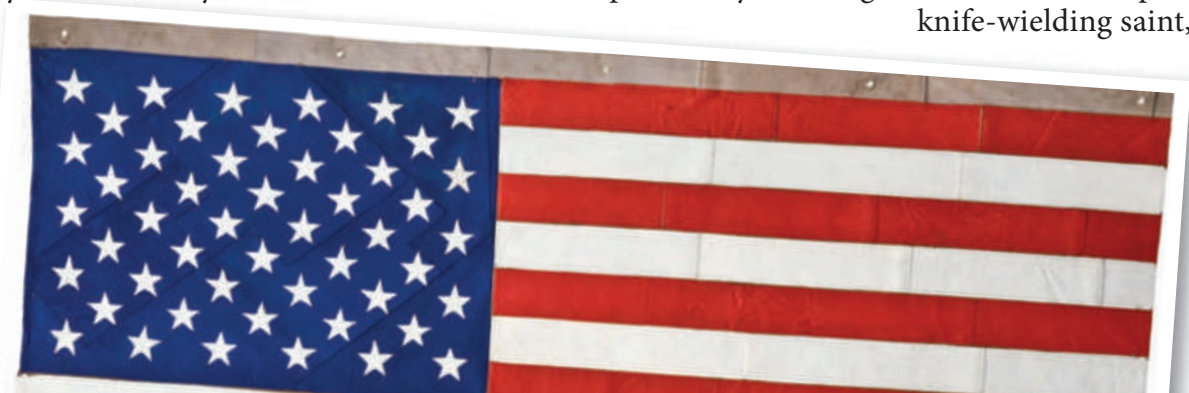
holds his own earthly hide, which bears a distorted imprint of the artist's own face, as Krasnow notes in the exhibition catalogue. Whether or not a Christian is resurrected in his or her own flesh is a long-standing matter of doctrinal dispute.

Closer to home, Krasnow is inviting us to think about "the skin history ... of the Americas, from the scalping of Native Americans on the frontier to the branding of slaves in the south, to the dropping of the A-bomb on Japan to the use of napalm

The flesh flag: sensationalist or sincere?

Section 1 of Title 4 of the United States Code, which prohibits desecration of the American flag, even though violation carries no stated penalty and comes into obvious conflict with the right to freedom of speech.

Whatever the legal implications, he tramples on taboos. We may be happy with gloves made from finest kid leather, looking much like the tanned skin used by Krasnow, but surely not if they were made from human skin. A worshipper may treasure a fragment of divine skin from a revered saint placed in a reliquary in a Spanish chapel, but we are unlikely to want such an item decorating our dinner table. We admire wonderful medieval illuminations on vellum ('veal' skin) and ancient leather-bound books, but are disconcerted to find that in the library in Vietnam and phosphorus bombs in Central America". He also tells us that his sister "suffered severe burns", from which she died in spite of extensive skin grafts from their parents. However, he resists the idea that there is a dominant "defining experience", either for him or for us.

I am convinced that his art is not merely sensational. He delves into a series of deep and complex strata in our awareness of what it is to be human, individually and under whatever banner we navigate the seas of life.

Martin Kemp is emeritus professor in history of art at the University of Oxford, Oxford, UK.
Flag from Flag Poll
by Andrew Krasnow
At GV Art, 49 Chiltern Street, London, until
17 March. See www.gvart.co.uk for details. 